EXPEIMENTAL EVOLUTION 
This Page Left Intentionally Blank 


\section{EXPERIMENTAL EVOLUTION}

Concepts, Methods, and Applications of Selection Experiments

EDITED BY

Theodore Garland, Jr.

Michael R. Rose

甲ㅗ

UNIVERSITY OF CALIFORNIA PRESS

Berkeley Los Angeles London 
University of California Press, one of the most distinguished university presses in the United States, enriches lives around the world by advancing scholarship in the humanities, social sciences, and natural sciences. Its activities are supported by the UC Press Foundation and by philanthropic contributions from individuals and institutions. For more information, visit www.ucpress.edu.

University of California Press

Berkeley and Los Angeles, California

University of California Press, Ltd.

London, England

(C) 2009 by the Regents of the University of California

Library of Congress Cataloging-in-Publication Data

Experimental evolution : concepts, methods, and applications of selection experiments / edited by Theodore Garland, Jr. and Michael R. Rose.

p. $\mathrm{cm}$.

Includes bibliographical references and index.

ISBN 978-0-520-24766-6 (cloth : alk. paper)—ISBN 978-0-520-26I80-8 (pbk. : alk. paper)

I. Evolution (Biology)—Research. 2. Natural selection-Research.

3. Evolution (Biology)—Experiments. 4. Animal breeding-Experiments.

I. Garland, Theodore, I956- II. Rose, Michael R. (Michael Robertson), I955-

$\mathrm{QH}_{3} 62 . \mathrm{E} 972010$

$576.8^{\prime} 2072-\mathrm{dc} 22$

2009015362

Manufactured in the United States of America

I6 I5 I4 I3 I2 II IO 09

I0 $\quad 9 \begin{array}{llllllll}8 & 7 & 6 & 5 & 4 & 3 & 2 & \text { I }\end{array}$

The paper used in this publication meets the minimum requirements of ANSI/NISO Z39.48-I992 (R I997) (Permanence of Paper). @)

Cover illustration: Scanning electron microscope composite of a Drosophila melanogaster (commonly known as the fruit fly). (C) Nicholas Monu. 
T.G. dedicates this to his family, including his grandparents (Mildred Snyder, Fred William Abildgaard, Jr., and Mary M. Wrenn), parents (Coleen Abildgaard and Theodore Garland), wife (Wendy Saltzman, PhD), and children (Theodore Garland, III and Jaden Lee Garland).

M.R.R. also dedicates this book to his family, near and far, Rose's and all. 
This Page Left Intentionally Blank 